\title{
The Impact of Care Upon Alzheimer Patient's Family Caregiver in Sulaimani City
}

\author{
Farida A. Kadir \\ Midwifery Department \\ Sulaimani Technical Institute \\ Sulaimani Polytechnic University \\ Sulaimani, Iraq \\ Farida.tahir@spu.edu.iq
}

\begin{abstract}
Family Care giving for relatives with Alzheimer, often includes assisting them with one or more activities of daily living, as Alzheimer is one of the progressive impairment disease in patient's physical and cognitive ability. The aim of this study is to assess the effect of being a family caregiver of Alzheimer patients in Sulaimani city. A cross sectional quantitative study carried out among family members who care for older patients with Alzheimer's disease. The instrument was designed and constructed by the researcher through an intensive review of literature and also through a series of meeting survey with caregivers in order to measure the variables underlying the present study. The data were obtained by the researcher, who interviewed families, structured questionnaire forms filled out with a total of 100 families. These were taken using a random sample of those families have Alzheimer's problem in Sulaimani city. The majority of participants were women with mean age 53.75 years old, married, housewives and with university education. More than half of the Caregiver was suffered from moderate to severe burdens. Rotated Component Matrix was used to get the level of effectiveness by a series of components according to important effects of the variables on Alzheimer disease. The researcher found that financial burden has taken the first order, followed by psychological and then social burden. The finding of the study shows a significant relationship between some demographic characteristics and the three dimensions of the burden. It appears that financial factor is in the first rank by a total variance (85.151), then psychological factors by a total variance (81.532) then the social factor by total variance (65.851). Financial factor was the strongest factor that impacted their family income. Some psychosocial oriented services are recommended for the caregivers in order to decrease the stress and help them to adapt to the situation. Some educational programs are also required to facilitate providing enhanced physical and psychological care. This study also recommends allocating salary for every patient to ease the financial burden on the caregivers.
\end{abstract}

Keywords: Caregiver, Alzheimer's disease, critical condition, social, psychological, financial, burden.

\section{INTRODUCTION}

Alzheimer disease (AD) is an age-related neurodegeneration disease, which affects about five million Americans each year. It is a progressive impairment in the patient's physical and cognitive ability. It also affects the development of behavioral disturbances. [1] All these may cause physical, emotional and financial burdens on the family caregiver [2]. Recently here are 47 million dementia patients all over the world. This number might pick-up to 75 million by 2030 and almost triple by 2050 [3]. Dementia becomes a widespread condition with grow up of the elderly population [4].AD represents $60-70 \%$ of dementia cases, making it a major problem in neurology and public health. A World Health Organization (WHO) report study in March12, 2012 recommends that every country should have its own strategy that focus on early diagnosis of dementia and improving the knowledge of caregivers and health professionals. In a study conducted in the UK with about 206 caregivers, it was found that when the caregivers supplied with places and people from whom they can get support, caring of demented patients, especially dependent patients, can cause a significant impact on the caregiver [5]. Physical and developmental burdens are more evident than emotional and social burdens [6].

Almost all over the world, AD patient's caregivers play a major role in dealing with their patients. However, stress may affect their ability to support and cause mental and physical problems [7]. Therefore, the family may face obstacles, for instance, the patient's behavioral problems. The caregiver's social supports by the family members predict the caregiver's distress. In 2010 dementia care giving costs, worldwide, were US \$ 604 billion, 70\% of which paid in Europe and North America [8]. In these countries' direct costs of social care and the informal care costs represented similar percentages, while the costs of medical care were much less. In countries with lower incomes the informal care represented the great majority, while direct social care costs were negligible [9]

The behavior of caregiver toward the dementia patients ranges from amiable devotion to abusive and aggressive behavior, which may turn to neglecting and mistreating of the patient [10]. To minimize the burden on caregivers and considering how difficult is the adaptation of an AD patient to the environmental changes and the great role of caregivers, it is very important to educate them the proper ways of care giving and to teach them how to take the necessary measures regarding the protection of their own social life and psychological health [11]. Economically, dementia can cost on the family caregiver, and this strategy can differ from country to another, due to the narrowing gap between the diagnosis and treatment. It is expected that these costs increase considerably in the few coming years in most developing countries [12].

The aim of this study is to assess the effect of being a family caregiver of Alzheimer patients in Sulaimani city. This aim will address the following objectives 
1. Assess the social burden of care upon family caregiver of Alzheimer patients

2. Assess the psychological burden of care upon family caregiver of Alzheimer patients

3. Assess the financial burden of care upon family caregiver of Alzheimer patients

4. Assess the relationship between some of the caregiver demographic data such as (age, gender, educational level and level of relationship) and the social, psychological and financial burden.

\section{METHODS AND MATERIALS}

This study is a quantitative descriptive study. The study participants were family members who care the older patients with Alzheimer disease.

The data were obtained by the researcher, who interviewed families in the clinic and home, structured questionnaire forms, which were filled out with 100 families. We choose a random sample from 100 families. These families have Alzheimer problem in Sulaimani city and its sufficient sample from statistical test KMO \&Bartlett's test.

The forms consisted of four dimensions such as (family demographic data, social, psychological and financial burden). The first part of the data was a caregiver demographic character, which includes (age, $\leq 30-->60$ ). The second dimension, consisted of 10 items about the social burden .The third dimension, consisted of 10 questions addressing the psychological status that affected the family, like (Insomnia, helplessness, worries, and feeling stress and pain).

The instrument was designed and constructed by the researcher through an intensive review of literature and also through a series of meeting survey with caregivers in order to measure the variables that underlying the present study.

This paper attempts to study and analyze some factors that may be affecting on Alzheimer disease by using a questionnaire technique to gather the sample data (the sample size equal 100 persons), then using suitable statistical methods to analyses these data. The questionnaire was classified into four classes: demographic, social, psychological and financial coordinators. Each class has some variables 10,10,10 and 6 variables respectively in the following:

\section{Socio Demographic Data Variables}

Age: classified into 5 categories less than 30, 31-40, 4150, 51-60 and more than 60.

Gender: classified into male and female.

Education level: classified into illiterate, literate, primary, secondary, undergraduate, graduate and postgraduate.

Residency: classified into urban and suburban.

Marital status: classified into single and married.

Works Type: classified into employed and retired.

Health status: classified into healthy and unhealthy.

Monthly income: classified into: sufficient, barely sufficient and insufficient.

House types: classified into: house and apartment.

Relationship: classified into: spouse, son and daughter.

\section{Social Data Variables}

1. Do you find it is difficult to deal with some of your patient habit which may result in conflicts between you and the patient?

2. Do your actions become more materialistic?

3. Do you have family members who do not want to keep in contact with the patient?

4. Do you have family members who refuse to believe that the condition was as far progressed as it was?

5. Do you feel that you are lonely or isolated socially as a result of your responsibility toward your patient?

6. Can you find different ways to cope with stress?

7. Are you exhausted and suffer from poor physical health due to your care giving act?

8. Have you restricted your personal time?

9. Do you feel embarrassed because of your patient's behavior?

10. Do you avoid inviting friends and acquaintances home because of your relative's problems?

\section{Psychology Data Variables}

1. Do you feel hopeless?

2. Do you suffer from insomnia as a result of thinking?

3. Do you suffer from aggressive behavior of your patient?

4. Has your patient repetitive behavior which may cause frustration to you?

5. Do you sometimes cry because of your distress?

6. Do you sometime neglect your health due to high responsibility toward your patient?

7. How frequent you become upset and angry from your patient?

8. Do you feel embarrassed by your relative's behavior?

9. Do you know how you cope with your own feelings?

10. Do you feel stressed between caring for your relative and trying to meet other responsibilities for your family or work?

\section{Financial Data Variables}

1. Does your income cover your expenses of your care giving act?

2. Does the case of your patient cost a lot of money?

3. Do you think that you don't have enough money to take care of your patient?

4. Does your income enable you to hire someone to take care of your patient?

5. Have your income changed because of the disease of your patient?

6. Do you borrow money to cover the treatment of your parent?

In this study, the researcher describes variables in data by central tendency measurements (mean) and variation measurement (standard deviations) insides Min, Max, and sample size for each variable. Principal component analysis (PCA)as a statistical technique that uses an orthogonal transformation to convert a set of observations of possible correlated variables and for each factor separately. Further, Rotated Component Matrix was used to identify the level of effectiveness of the disease on the caregivers. 


\section{RESULTS}

\subsection{Socio Demographic data variables}

Table1: Frequencies, percentage for demographic variables Demographic data

\begin{tabular}{|c|c|c|}
\hline \multicolumn{3}{|c|}{ Age } \\
\hline$\leq 30$ & 6 & 6 \\
\hline $30-40$ & 14 & 14 \\
\hline $40-50$ & 14 & 14 \\
\hline $50-60$ & 27 & 27 \\
\hline More 60 & 39 & 39 \\
\hline \multicolumn{3}{|c|}{ Gender } \\
\hline Male & 3 & 3 \\
\hline Female & 97 & 97 \\
\hline \multicolumn{3}{|c|}{ Educational level } \\
\hline Primary and secondary & 2 & 2 \\
\hline $\begin{array}{l}\text { Undergraduate } \\
\text { (Institute) }\end{array}$ & 26 & 26 \\
\hline $\begin{array}{l}\text { Undergraduate } \\
\text { (Bachelor's degree) }\end{array}$ & 69 & 69 \\
\hline postgraduate & 3 & 3 \\
\hline \multicolumn{3}{|c|}{ Marital status } \\
\hline Married & 88 & 88 \\
\hline Single & 12 & 12 \\
\hline \multicolumn{3}{|c|}{ Types of work } \\
\hline Employee & 50 & 50 \\
\hline Retire & 50 & 50 \\
\hline \multicolumn{3}{|c|}{ Chronic disease } \\
\hline Yes & 41 & 41 \\
\hline No & 59 & 59 \\
\hline \multicolumn{3}{|c|}{ Monthly income } \\
\hline Sufficient & 10 & 10 \\
\hline Barely Sufficient & 85 & 85 \\
\hline Insufficient & 5 & 5 \\
\hline \multicolumn{3}{|c|}{ House type } \\
\hline House & 94 & 94 \\
\hline Apartment & 6 & 6 \\
\hline \multicolumn{3}{|c|}{ Relationship } \\
\hline Spouse & 19 & 19 \\
\hline Son & 3 & 3 \\
\hline Daughter & 78 & 78 \\
\hline
\end{tabular}

Table (1): Distribution of the study sample, (100) caregivers in Sulaimani city by their socio-demographic characteristics (age, gender, level of education, marital status, occupation monthly income, house type, health status and relationship). Caregivers were mostly women, married, housewives and with university education. Caregiver burden in over half of the cases was moderate to severe
Table 2: The relationship between Socio Demographic data and Social, Psychological and Financial factors

\begin{tabular}{|c|c|c|c|c|}
\hline \multicolumn{2}{|c|}{ Spearman's rho correlation } & \multirow{2}{*}{$\begin{array}{l}\begin{array}{l}\text { Social } \\
\text { Avg }\end{array} \\
.271\end{array}$} & \multirow{2}{*}{ 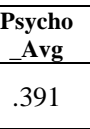 } & \multirow{2}{*}{$\begin{array}{l}\text { Finance_ } \\
\text { Avg } \\
-.136-\end{array}$} \\
\hline Age & $\begin{array}{l}\text { Correlation } \\
\text { Coefficient }\end{array}$ & & & \\
\hline & Sig. (2-tailed) & .006 & .000 & .179 \\
\hline \multirow[t]{2}{*}{ Gender } & $\begin{array}{l}\text { Correlation } \\
\text { Coefficient }\end{array}$ & .177 & $-.078-$ & $-.196-$ \\
\hline & Sig. (2-tailed) & .078 & .440 & .050 \\
\hline \multirow[t]{2}{*}{ Education level } & $\begin{array}{l}\text { Correlation } \\
\text { Coefficient }\end{array}$ & .423 & $-.032-$ & $-.528-$ \\
\hline & Sig. (2-tailed) & .000 & .753 & .000 \\
\hline \multirow[t]{2}{*}{ Marital status } & $\begin{array}{l}\text { Correlation } \\
\text { Coefficient } \\
\end{array}$ & $-.405-$ & $-.307-$ & $.350^{* *}$ \\
\hline & Sig. (2-tailed) & .000 & .002 & .000 \\
\hline \multirow[t]{2}{*}{ Works Type } & $\begin{array}{l}\text { Correlation } \\
\text { Coefficient }\end{array}$ & $.503^{* *}$ & .118 & $-.461-^{* *}$ \\
\hline & Sig. (2-tailed) & .000 & .244 & .000 \\
\hline \multirow[t]{2}{*}{ Health status } & $\begin{array}{l}\text { Correlation } \\
\text { Coefficient }\end{array}$ & $.420^{* *}$ & $.180^{*}$ & $-.360-$ \\
\hline & Sig. (2-tailed) & .000 & .073 & .000 \\
\hline \multirow[t]{2}{*}{ Monthly Income } & $\begin{array}{l}\text { Correlation } \\
\text { Coefficient } \\
\end{array}$ & .019 & $-.194-$ & .121 \\
\hline & Sig. (2-tailed) & .849 & .053 & .232 \\
\hline \multirow[t]{2}{*}{ Relationship } & $\begin{array}{l}\text { Correlation } \\
\text { Coefficient }\end{array}$ & $.256^{*}$ & $-.213-$ & $-.469-^{* *}$ \\
\hline & Sig. (2-tailed) & .010 & .034 & .000 \\
\hline
\end{tabular}

Table 2 shows the relationship between demographic data (age, gender, etc.) with the dimensions social, psychological and financial), this study has used spearman's rho as a non-parametric test to study the relationship between these variables, and the table below explains that:

\subsection{Analyses of the effects of Alzheimer disease on social, psychology and financial factors)}

We analyzed our data (socials factor, psychological factor and financial factor) to assess the effects on Alzheimer disease by using principal component analysis (PCA) as a statistical technique that uses an orthogonal transformation to convert a set of observations of possibly correlated variables and for each factor partly(by three parts) as follow:

\section{a. Social factor}

In social factors we had 10 variables (questions) and we wanted to study and analyze, which one has more significance in correlation with Alzheimer disease.

Table 3: Cumulative variance of social factor

\begin{tabular}{llllll}
\hline $\begin{array}{l}\text { Co } \\
\text { mp. }\end{array}$ & \multicolumn{2}{l}{ Initial Eigenvalues } & \multicolumn{3}{c}{$\begin{array}{l}\text { Extraction Sums of } \\
\text { Squared Loadings }\end{array}$} \\
\cline { 2 - 6 } & Total & $\begin{array}{l}\text { \% of } \\
\text { Varianc } \\
\text { e }\end{array}$ & $\begin{array}{l}\text { Cumulat } \\
\text { ive \% }\end{array}$ & Total & $\begin{array}{l}\text { \% of } \\
\text { Varianc } \\
\text { e }\end{array}$ \\
\hline $\mathbf{1}$ & 4.174 & 41.739 & 41.739 & 4.174 & 41.739 \\
\hline $\mathbf{2}$ & 1.746 & 17.463 & 59.202 & 1.746 & 17.463 \\
\hline $\mathbf{3}$ & 1.229 & 12.287 & 71.489 & 1.229 & 12.287 \\
\hline $\mathbf{4}$ & 1.004 & 10.043 & 81.532 & 1.004 & 10.043 \\
\hline $\mathbf{5}$ & .583 & 5.829 & 87.361 & & \\
\hline $\mathbf{6}$ & .530 & 5.297 & 92.658 & & \\
\hline $\mathbf{7}$ & .372 & 3.719 & 96.377 & & \\
\hline $\mathbf{8}$ & .281 & 2.808 & 99.186 & & \\
\hline $\mathbf{9}$ & .081 & .814 & 100.000 & & \\
\hline $\mathbf{1 0}$ & 1.000 & $1.001 \mathrm{E}-$ & 100.000 & & \\
\hline
\end{tabular}


Table 3.1: Rotated Component Matrix

\begin{tabular}{|c|c|c|c|}
\hline \multirow{2}{*}{ Social components } & \multicolumn{3}{|c|}{ Component } \\
\hline & 1 & 2 & 3 \\
\hline $\begin{array}{l}\text { Do you find it is difficult to deal with } \\
\text { some of your patient habit with may } \\
\text { result in conflicts between you and the } \\
\text { patient? }\end{array}$ & .654 & .230 & $\begin{array}{c}- \\
.294 \\
-\end{array}$ \\
\hline $\begin{array}{l}\text { Do your actions become more } \\
\text { maternalistic? }\end{array}$ & .172 & .824 & $\begin{array}{c}- \\
.066 \\
- \\
\end{array}$ \\
\hline $\begin{array}{l}\text { Do you have family members who do not } \\
\text { want to keep in contact with the patient? }\end{array}$ & .135 & .092 & .867 \\
\hline $\begin{array}{l}\text { Do you have family members who refuse } \\
\text { to believe that the condition was as far } \\
\text { progressed as it was? }\end{array}$ & $\begin{array}{c}- \\
.057 \\
- \\
\end{array}$ & .182 & .885 \\
\hline $\begin{array}{l}\text { Do you feel that you are lonely or isolated } \\
\text { socially as a result of your responsibility } \\
\text { toward your patient? }\end{array}$ & .737 & .079 & .053 \\
\hline $\begin{array}{l}\text { Can you find different ways to cope with } \\
\text { stress? }\end{array}$ & $\begin{array}{c}- \\
.023 \\
- \\
\end{array}$ & .830 & .185 \\
\hline $\begin{array}{l}\text { Are you exhausted and suffer from poor } \\
\text { physical health due to your caregiving } \\
\text { act? }\end{array}$ & .111 & .784 & .186 \\
\hline Have you restricted your personal time? & .635 & .044 & .200 \\
\hline $\begin{array}{l}\text { Do you feel embarrassed because of your } \\
\text { patient behavior? }\end{array}$ & .846 & .017 & $\begin{array}{c}- \\
.080 \\
- \\
\end{array}$ \\
\hline $\begin{array}{l}\text { Do you avoid inviting friends and } \\
\text { acquaintances home because of your } \\
\text { relative's problems? }\end{array}$ & .768 & .048 & .089 \\
\hline
\end{tabular}

First factor, get variance equal to (30.643) from overall variance and it includes the following five variables (questions):

'Do you feel that you are lonely or isolated socially as a result of your responsibility toward your patient' by loading value (0.737), 'Have you restricted your personal time' by loading value (0.635), 'Do you feel embarrassed because of your patient behavior' by loading value (0.846) and finally 'Do you avoid inviting friends and acquaintances home because of your relative's problems' by loading $(0.768)$

Second Factor: The second component gets variance equal to (21.182) from overall variance and it includes the following three variables (questions):

'Do your actions become more materialistic' by loading(0.824), 'Can you find different ways to cope with stress' by loading(0.830) and 'Are you exhausted and suffer from poor physical health due to your care' giving act by loading value (0.784).

Third Factor: The third component gets variance equal to (14.026) from overall variance and it includes the following two variables (questions): 'Do you have family members who do not want to keep in contact with the patient' by loading value (0.867) and 'Do you have family members who refuse to believe that the condition was as far progressed' as it was by loading (0.885).

\section{b. Psychological factors}

In psychological factor we have 10 variables and we want to study and analyze which one has more significance correlated with Alzheimer disease.

Table 4 in below represent Kaiser-Meyer-Olkin Measure and Bartlett's Test of Sphericity to study the sample sufficiency; It's clear the sample information has a significant sufficiency because Sig value less than 0.0

Table 4: Cumulative variance of psychological factors

\begin{tabular}{llllll}
\hline \multirow{2}{*}{ Com } & \multicolumn{3}{c}{ Initial Eigen values } & \multicolumn{2}{c}{$\begin{array}{c}\text { Extraction Sums of } \\
\text { Squared Loadings }\end{array}$} \\
\cline { 2 - 6 } & Total & $\begin{array}{l}\text { \% of } \\
\text { Variance }\end{array}$ & $\begin{array}{l}\text { Cumulativ } \\
\mathrm{e} \%\end{array}$ & Total & $\begin{array}{l}\text { \% of } \\
\text { Variance }\end{array}$ \\
\hline $\mathbf{1}$ & 4.174 & 41.739 & 41.739 & 4.174 & 41.739 \\
\hline $\mathbf{2}$ & 1.746 & 17.463 & 59.202 & 1.746 & 17.463 \\
\hline $\mathbf{3}$ & 1.229 & 12.287 & 71.489 & 1.229 & 12.287 \\
\hline $\mathbf{4}$ & 1.004 & 10.043 & 81.532 & 1.004 & 10.043 \\
\hline $\mathbf{5}$ & .583 & 5.829 & 87.361 & & \\
\hline $\mathbf{6}$ & .530 & 5.297 & 92.658 & & \\
\hline $\mathbf{7}$ & .372 & 3.719 & 96.377 & & \\
\hline $\mathbf{8}$ & .281 & 2.808 & 99.186 & & \\
\hline $\mathbf{9}$ & .081 & .814 & 100.000 & & \\
\hline $\mathbf{1 0}$ & $1.000 \mathrm{E}-$ & $1.001 \mathrm{E}-$ & 100.000 & & \\
\hline
\end{tabular}

From the table (4) above show, 4 components only by Extraction Sums of Squared Loadings (cumulative variance) equal to (81.532).

Table 4.1: Rotated Component Matrix of psychological factor

\begin{tabular}{|c|c|c|c|c|}
\hline \multirow{2}{*}{ Psychological factor } & \multicolumn{4}{|c|}{ Component } \\
\hline & 1 & 2 & 3 & 4 \\
\hline \multirow[t]{2}{*}{ Do you feel hopeless? } & & & - & \\
\hline & .712 & .639 & $\begin{array}{l}.095 \\
-\end{array}$ & -.025 \\
\hline $\begin{array}{l}\text { Do you suffer from insomnia as a } \\
\text { result of thinking? }\end{array}$ & $-.007-$ & $\begin{array}{l}- \\
.051 \\
-\end{array}$ & $\begin{array}{l}- \\
.106 \\
-\end{array}$ & .892 \\
\hline $\begin{array}{l}\text { Do you suffer from aggressive } \\
\text { behavior of your patient? }\end{array}$ & .712 & .639 & $\begin{array}{l}- \\
.095 \\
-\end{array}$ & -.025 \\
\hline $\begin{array}{l}\text { Has your patient repetitive } \\
\text { behavior which may cause } \\
\text { frustration to you? }\end{array}$ & .794 & .502 & $\begin{array}{l}- \\
.088 \\
-\end{array}$ & .029 \\
\hline $\begin{array}{l}\text { Do you sometime cry because of } \\
\text { your distress? }\end{array}$ & $-.117-$ & $\begin{array}{l}- \\
.878 \\
-\end{array}$ & .134 & .085 \\
\hline $\begin{array}{l}\text { Do you sometime neglect your } \\
\text { health due to high responsibility to } \\
\text { your patient? }\end{array}$ & .242 & .596 & .385 & .477 \\
\hline $\begin{array}{l}\text { How frequent you become upset } \\
\text { and angry from your patient? }\end{array}$ & $-.677-$ & $\begin{array}{l}- \\
.037 \\
-\end{array}$ & $\begin{array}{l}- \\
-325 \\
-\end{array}$ & .327 \\
\hline $\begin{array}{l}\text { Do you feel embarrassed by your } \\
\text { relative's behavior? }\end{array}$ & .048 & $\begin{array}{l}- \\
.314 \\
-\end{array}$ & .762 & $-.189-$ \\
\hline $\begin{array}{l}\text { Do you know how to cope with } \\
\text { your own feelings? }\end{array}$ & $-.161-$ & .100 & .876 & .035 \\
\hline $\begin{array}{l}\text { Do you feel stressed between caring } \\
\text { for your relative and trying to meet } \\
\text { other responsibilities for your } \\
\text { family or work? }\end{array}$ & .795 & $\begin{array}{l}- \\
.026 \\
-\end{array}$ & $\begin{array}{l}- \\
.230 \\
-\end{array}$ & .349 \\
\hline
\end{tabular}

From table 4.1 Rotated Component Matrix has done, the result gets four components according to importance psychology significance variables on Alzheimer disease.

First Factor: The first component gets variance equal to (41.739) from overall variance and it's including the following five variables (questions):

'Do you feel hopeless' by loading value (0.712), 'Do you suffer from aggressive behavior of your patient' by loading value $(0.712)$, 'Has your patient repetitive behavior which may cause frustration to you' by loading 
value (0.794), 'How frequent you become upset and angry from your patient' by loading value (-0.677) and finally 'Do you feel stressed between caring for your relative and trying to meet other responsibilities for your family or work’ by loading (0.795).

Second Factor: The second component gets variance equal to (17.463) from overall variance and it's including the following two variables (questions):

Do you sometime cry because of your distress' by loading (-0.878), 'Can you find different ways to cope with stress' by loading (0.830) and 'Do you sometimes neglect your health due to high responsibility to your patient by loading a value (0.596).

Third Factor: The third component gets variance equal to (12.287) from overall variance and it's including the following two variables (questions):

'Do you feel embarrassed by your relative's behavior 'by loading value (0.762) and 'Do you know how you cope with your own feelings’ by loading value (0.876).

Fourth facto: The fourth component gets variance equal to (10.043) from overall variance and it's included only one variable (question): 'Do you suffer from insomnia as a result of thinking’ by loading value (0.892).

\section{c. Financial factor}

In financial factor we have only 6 variables (questions) and we want to study and analyze which one has more significant correlation with Alzheimer disease.

Table 5: Total Variance of Financial factors

\begin{tabular}{|c|c|c|c|c|c|}
\hline \multirow{2}{*}{$\begin{array}{l}\text { Co } \\
\text { mp }\end{array}$} & \multicolumn{3}{|c|}{ Initial Eigen values } & \multicolumn{2}{|c|}{$\begin{array}{l}\text { Extraction Sums of } \\
\text { Squared Loadings }\end{array}$} \\
\hline & $\begin{array}{l}\text { Tot } \\
\text { al }\end{array}$ & $\begin{array}{l}\% \text { of } \\
\text { Variance }\end{array}$ & $\begin{array}{l}\text { Cumulativ } \\
\text { e \% }\end{array}$ & Total & $\begin{array}{l}\% \text { of } \\
\text { Variance }\end{array}$ \\
\hline 1 & $\begin{array}{l}2.3 \\
83\end{array}$ & 39.710 & 39.710 & 2.383 & 39.710 \\
\hline 2 & $\begin{array}{l}1.5 \\
22\end{array}$ & 25.374 & 65.084 & 1.522 & 25.374 \\
\hline 3 & $\begin{array}{l}1.2 \\
04\end{array}$ & 20.067 & 85.151 & 1.204 & 20.067 \\
\hline 4 & $\begin{array}{l}.56 \\
9\end{array}$ & 9.478 & 94.630 & & \\
\hline 5 & $\begin{array}{l}.23 \\
8 \\
\end{array}$ & 3.959 & 98.589 & & \\
\hline 6 & $\begin{array}{l}.08 \\
5\end{array}$ & 1.411 & 100.000 & & \\
\hline
\end{tabular}

From the table (5) above, this study found the 3 components only by extraction sums of squared loadings (cumulative variance) equal to (85.151).

Table 5.1: Rotated Component Matrix

\begin{tabular}{llll}
\hline \multirow{2}{*}{ Financial factors } & \multicolumn{3}{l}{ Component } \\
\cline { 2 - 4 } & 1 & 2 & 3 \\
\hline $\begin{array}{l}\text { Does your income cover your expenses of } \\
\text { your care giving act? }\end{array}$ & .948 & - & - \\
& & .184 & .01 \\
\hline $\begin{array}{l}\text { Does the case of your patient cost a lot of } \\
\text { money? }\end{array}$ & .528 & .357 & \multicolumn{1}{l}{.68} \\
\hline $\begin{array}{l}\text { Do you think that you don't have enough } \\
\text { money to take care of your patient? }\end{array}$ & - & - & .94 \\
\hline $\begin{array}{l}\text { Does your income enable you to hire } \\
\text { someone to take care of your patient? }\end{array}$ & .129 & .159 & 5 \\
& -260 & - & - \\
\hline $\begin{array}{l}\text { Have your income changed because of the } \\
\text { disease of your patient? }\end{array}$ & - & .766 & .11 \\
\hline
\end{tabular}

\begin{tabular}{llll}
\hline & - & $0-$ \\
\hline Do you borrow money to cover the & - & .212 & - \\
treatment of your patient? & .919 & .01 \\
& - & $9-$ \\
\hline
\end{tabular}

From the table (5.1) Rotated Component Matrix has done and the study found three components according to importance correlated of the financial variables with Alzheimer disease.

First Factor: The first component gets variance equal to (39.710) from overall variance and it's including the following two variables (questions):

'Is your income covering your expenses of your Care giving act' by loading value (0.948) and Do you borrow money to cover the treatment of your patient by loading a value (-0.919).

Second Factor: The second component gets variance equal to (25.374) from overall variance and it's including the following two variables (questions):

'Does your income enable you to hire someone to take care of your patient' by loading (-0.766) and 'Does your income had changed because of the disease of your patient’ by loading (0.885).

Third Factor: The third component gets variance equal to (20.067) from overall variance and it's included only the following two variables (questions):

Does the case of your patient cost allot of money by loading value (0.686) and do you think that you don't have enough money to take care of your patient with loading (0.945)

Finally, if we want to compare between these three factors (social, psychology and finance) which one has more effect on Alzheimer disease than other by caregivers answers and depend upon total variance in principal components analysis, it's appearing that financial factor is in the first order by a total variance equals (85.151), then psychological factor by a total variance equals to (81.532) and in the third order is social factor by a total variance equal to (65.851).

\section{DISCUSSION}

Caregiving includes performing one or more activities of living such as bathing, dressing, giving treatments and other daily needs of the person like, shopping, using transportation and paying bills. These activities may include providing emotional support to these persons [13]. In Sulaimani most of the patients with Alzheimer live with a family caregiver due to the lack of community resources and rehabilitation programs, which can afford the services on the scientific bases, while family caregivers could not be able to do it scientifically. Thus, a great extent of the burden will be imposed on the caregivers. These results recommended a close supervision of the mental, psychological and social status of the caregivers.

Regarding the caregiver's socio-demographic data, this study found that about half of the primary caregivers, are retired and care for their parents and this explain why the financial burden is higher than the other two components burden. This finding is consistent with [14], which stated that health care expenditures among persons with 
dementia were substantially larger than those of other diseases. These places a large financial burden on families, that are least prepared for financial risk. Women were more likely deal with their patients as the first caregiver in the family to cover their patient's requirement. This finding is consistent with [15] which stated that the majority of Alzheimer's caregivers are wives and daughters. Hence, female caregivers were spending more time rather than male [16]. This is also supported by the survey of Alzheimer's Association Women and Alzheimer's Poll, which interviewed both men and women caregivers in 2014 and found that 67 percent of those who provide care giving for 21 to more than 60 hours per week were women[17]. As a consequence, women caregivers may be impacted more than men. There are evidences suggesting that these differences arise because the caregiver burden is proportional to the number of hours of care giving and cognitive function .Familial and social support together with care giving experience could alleviate care giving burden and improve the relation between the caregiver and the patient .This may be achieved through focusing on patient factors and promoting care giving act [18]. Significant impacts on the health of the caregiver and reduced quality of life are strongly associated with the burden on the caregiver [19].

The current study indicated that $69 \%$ of caregivers were with a university degree. These are inconsistent with the result of the study [20] which stated that approximately $40 \%$ of the caregivers were educated and have a bachelor degree. In terms of relationship, the majority of the caregivers (78\%) were patient's daughters followed by $15 \%$ patients' spouses and 3\% their sons. This finding is inconsistent with the [21], which reported that over one third of dementia caregivers are daughters.

Through using Rotated Component Matrix, each study domain was classified into many components depending on the level of effectiveness of the disease on the caregiver's life. More dementia caregivers were classified as having a high level of burden than caregivers of people without dementia (46 percent versus 38 percent) [22], In regards to the social impact of Alzheimer disease, feeling of loneliness and isolation have taken the first component factors, followed by their suffering from restricted personal time. Their communications were also affected; as they said they could not be able to invite a friends or relatives. In terms of the second component in social burden, the participant of the study stated that they attempted to find ways to stress out. Care giving burden is associated with reduced quality of life and limited relationship and also has a direct impact on friendship [23]Therefore, cooperation in the family and trying to help each other has been reported by the caregivers as a positive feeling that reduced the level of stress [24].

According to the importance of psychological variables on Alzheimer disease, the highest impact of this factor on the caregivers is their feeling: such as hopelessness, practicing aggressive behavior, upset, and passiveness in meeting other responsibilities for their family. The second component factor is to stress out by crying. They also suffer from being neglected and they are not able to deal with their health status. The third component factor is almost less effective on their quality of life as they are embarrassed because of their patient's behavior .They suffer from insomnia as a result of thinking ; a matter has the lowest effect. In a comparative study, which conducted among two groups of populations: one of them caregiver of the dementia and the other not, it was found that approximately $30-40 \%$ of the caregivers were suffered from depression compared with 5-17\% of noncaregivers [25].

Regarding the importance of correlation between the financial variables and Alzheimer disease, the first component factors adjusted by the participants is the effect of treatment of the disease on their income, as it was reported as the strongest factor that impacted their financial status, followed by less likely factors that they don't have money. Most of the caregivers in this study were in the barely sufficient level of economy. The severity of the Alzheimer's disease might play a vital role in impacting the family financially [26)].The expenditure of dementia care are costing more than the other disease The study stated that many of the expenses were 'uninsured', which may cause a larger financial burden on the family [27].

\section{CONCLUSIONS}

This study confirmed that financial factor was the strongest factor that impacted their family income. Therefore, it's appearing that financial factor is in the first order by a total variance equals (85.151), then psychological factor by a total variance equals to (81.532) and in the third order is social factor by a total variance equal to (65.851). Psychosocial oriented services should be established for the Alzheimer's disease to help them in case of occurrence of psychological problems. Further, educational programs are recommended in order to educate caregivers in how to deal with their patients and cope with the situation.

\section{REFERENCES}

[1] A. Vignini,AGiulietti, L. Nanetti, F. Raffaelli Leandro. "Current Diabetes Reviews” 9(3), pp. 218-227. 2013

[2] DA. Casey, D. Antimisiaris, J. O'Brien "Drugs for Alzheimer'sDisease: Are They Effective?”. Journal List; 35(4), PP. 208-211. 2010.

[3] B.Winblad, P. Amouyel, S.Andrieu, C Ballard, C.Brayne, H..Brodaty et al.,"DefeatingAlzheimer"s disease and other dementias : a priority for European science and society.” Lancet Neurol;15(10):1007-1008. 2016.

[4] R. Brookmeyer, N. Abdalla, CH. Kawas, MM. Corrada. "Forecasting the prevalence of preclinical and clinical Alzheimer's disease in the United States” Alzheimer's \& Dementia; 14 (2). pp 121-129. 2017.

[5] A. Innes, F. Kelly, and L. McCabe "Challenges of developing a dementia strategy: the case of Malta. In Key issues in evolving dementia care” International theory-based policy and practice. 1 (2). Pp. 133-142. 2016.

[6] E. Elifkoca, O. Taskaplljoglu, M. Bakar"Caregiver Burden in different Stages of Alzheimer"s disease”.NoroPsikiyatrArs. 54(1): 82-86. 2017.

[7] A. Girgis, S. Lambert, C. Johnson, A. Waller, D Currow "Physical, Psychosocial, Relationship, and Economic Burden of Caring for People With Cancer” J OncolPract.. 9(4): 197-202. 2013.

[8] M. Bevans,E. Stemberg "Caregiving Burden, Stress, and Health Effects Among Family Caregivers” Journal American Medical Association 307(4). pp. 398-403. 2012.

[9] E. Berglund, P. Lytsy, R.Westerling. "Health and wellbeing in informal caregivers and non-caregivers: A comparative crosssectional study of the Swedish general population”. Health and Quality of Life Outcomes. 13(1). pp.1-11. 2015. 
[10] M. Jakobsen, P.B.Poulsen, T.Reiche , N.P.Nissen, J. Gundgaard “ Costs of Informal Care for People Suffering from Dementia. Dementia and geriatric" Dementia and Geriatric Cognitive Disorders EXTRA. 54(1). pp 82-86. 2011.

[11] D. Dettmore, A. Kolanowski, M. Boustani“Aggression in Persons with Dementia”Geriatric Nursing Journal. pp 30(1): 8-17. 2012.

[12] A. Leslie, R. L. Allison, J G.Carolyn, S. R. Craig: "Treating Anger and Aggression in Military Populations: Research Updates and Clinical Implications" Clinical Psychology Science and Practice 19(3). pp 305-322. 2012.

[13] R. Bateman, C. Xiong, TL.Benzinger, AM. Fagan, A.Goate, NC.Fox, et al. "Clinical and biomarker changes in dominantly inherited Alzheimer"s disease". The New England Journal of Medicine., 367(9), pp795-804. 2012

[14] K. Amy, R.Gorges."The Burden of Health Care Costs for Patients With Dementia in the Last 5 Years of Life”, Annals of internal medicine Journal. 163(10),. pp 729-736. 2015.

[15] E.M.Friedman, R.A.hih,K.M.Langa. "prevalencand predictors of informal caregiving for dementia”. Health Aff; 34(10):1637-41.16. 2015

[16] B. Akpınar, O. Küçükgüçlü, G. Yener. "Effects of Gender on Burden Among Caregivers of Alzheimer's Patients”. Journal of Nursing Scholarship.43(3). pp.248-54. 2011.

[17] Alzheimer"s Association "Alzheimer"s Association Report 2019 Alzheimer"s disease facts and figures" Alzheimer"s\& Dementia 15; pp 321-387. 2019.

[18] L. Fernandes and C. Paúl “Aging \& Mental Health” Front Aging Neuroscince. 9; pp 1-3. 2017.

[19] R. Schulz, SH. Belle, SJ.Czaja, KA. McGinnis A. Stevens, S. Zhang "Long-term care placement of dementia patients and caregiver health and well-being”. Journal American Medical Association., 292(8). pp 961-967. 2004.

[20] National Alliance for Caregiving in Partnership with the Alzheimer"s Association Dementia.The American Journal of Geriatric Psychiatry. 23(4,), pp 391-402. 2015.

[21] EM. Friedman, RA. Shih, KM.Langa, MD.Hurd. "prevalence and predictors of informal caregiving for dementia”. Health Affairs;34(10), pp1637-1641. 2015.

[22] M. Miyashita., A. Yamaguchi, M. Kayama, Y. Narita, N. Kawada, M. Akiyama et al,. "Validation of the Burden Index of Caregivers (BIC), a multidimensional short care burden scale from Japan” Health Qual Life Outcomes. 4:(52.). pp 1-9. 2006.

[23] G. Fadden ,P.Bebbington,L. Kuipers "The burden of care: the impact of functional psychiatric illness on the patiente's family. British Journal of Psychiatry.;150:. pp285--292. 2018.

[24] J. Lloyd, T Patterson, J. Muers "The positive aspects of caregiving in dementia: A critical review of the qualitative literature”. Dementia. 15(6). pp1534-61. 2016.

[25] S.Atteih, L. Mellon, P. Hall, L Brewer, F. Horgan D. Williams et al. "Implications of stroke for caregiver outcomes: Findings from the ASPIRE-S Study”. International journal of Stroke. 10. pp 918923. 2015.

[26] R.Preidt, “The high cost of Alzheimer's”, Health Day reporter about sharp increase in Alzheimer's disease cases. Deaths and costs are stressing the US health care system and caregivers. 2018.

[27] S. Amy. R. Gorges, S. Jonathan. "The Burden of Health Care Costs for Patients with Dementia in the Last 5 Years of Life" Annals of Internal Medicine;163 (10). pp 729-736. 2015. 